\title{
Defense factors in clam extrapallial fluids
}

\author{
Bassem Allam, Christine Paillard *
}

UMR CNRS 6539, Institut Universitaire Européen de la Mer, Université de Bretagne Occidentale, F-29287 Brest Cedex, France

\begin{abstract}
The extrapallial fluid of clams is located between the external epithelium of the mantle and the inner face of the shell. The pallial line separates the fluid into central and peripheral extrapallial fluids (CEF and PEF, respectively). These fluids are the sites of biomineralization, but their role in other biological processes, such as defense, remains unknown. A comparative study of some characteristics of the cellular and humoral fractions of the extrapallial fluids and hemolymph of the Manila clam Ruditapes philippinarum was carried out. Both CEF and PEF contained abundant hemocytes comparable to those found in hemolymph. Total and viable hemocyte counts were high especially in the CEF. Extrapallial fluid cell lysate and supernatant showed significant bacteriolytic (lysozyme-hke) activity. The CEF was found to be bacteriologically sterile. This sterility may result from the presence in the CEF of significant defense factors in the form of numerous macrophage-like cells and high lysozyme activity. These findings are of interest in the case of bivalves susceptible to shell diseases such as $R$. philippinarum, which is susceptıble to a bacterial disease caused by Vibrio tapetis.
\end{abstract}

KEYWORDS: Bivalve Ruditapes philippinarum Extrapallaal fluid Shell hiquor Hemocyte Defense

\section{INTRODUCTION}

Because molluscs have an open circulatory system, hemocytes are present in sinuses throughout all soft tissues (Cheng 1981, Bayne 1983). In addition, recent findings confirmed the presence of hemocytes in oyster shell liquor (Mulholland \& Friedl 1994, Mulholland et al. 1995, Paillard et al. 1996). Many studies concerning molluscan hemolymph have already been carried out, but little is known about the other body fluids, such as the pallial fluid (or pallial cavity fluid) and extrapallial fluid, which is located between the external epithelium of the mantle and the inner face of the shell. A few studies dealing with oyster pallial cavity fluid have demonstrated the presence of lysozyme (McDade \& Tripp 1967) and agglutinins (Fisher 1992) originated from mucus secretions of pallial organs. Most studies of extrapallial fluid deal with the ionic regulation and $\mathrm{CaCO}_{3}$ formation that occur in this medium, rather than with the biological factors that may play a role in the defense system (Wilbur 1964, Crenshaw 1972, Misogianes \& Chasteen 1979, Wilbur \& Saleuddin 1983).

In the Manila clam Ruditapes philippinarum, as in other Venerideae, the pallial line separates the extra-

-Addressee for correspondence. E-mail: paillard@univ-brest.fr pallial space into 2 compartments: the central compartment contains the central extrapallial fluid or CEF, whereas the peripheral compartment contains the peripheral extrapallial fluid or PEF (Bartoli 1974, Paillard \& Maes 1994). This bivalve species is affected by a bacterial shell disease, the Brown Ring Disease, which is caused by a Vibrio strain first called Vibrio P1 (Paillard \& Maes 1990, Paillard et al. 1994) and more recently named Vibrio tapetis (Borrego et al. 1996). This disease is characterized by a conchiolin deposit on the inner face of the shell, within the extrapallial space (Paillard et al. 1989, Paillard \& Maes 1994). Because the characteristic disease syndrome is located outside of the soft tissue, it is relevant to evaluate the clam's defense potential in the extrapallial fluid, the medium that surrounds the body and in which the signs of disease occur.

In microbial diseases of molluscs, 2 major defense mechanisms are generally involved in the early stages of infection: (1) phagocytosis by hemocytes and (2) spontaneous antibacterial activity of mollusc humoral factors (see reviews by Cheng 1981, Bayne 1983, Chu 1988). The purpose of this work was to examine and compare some characteristics of the cellular and humoral fractions of the extrapallial fluid (CEF and PEF) and of the hemolymph (HE) of Ruditapes philip- 
pinarum. The parameters investigated were mainly cell morphology, cell number and viability, and activity of lysozyme, which is considered to be a natural antibacterial factor (Cheng \& Rodrick 1974, Rodrick \& Cheng 1974).

\section{MATERIALS AND METHODS}

Specimens. Adult ( 35 to $40 \mathrm{~mm}$ ) Manila clams Ruditapes philippinarum with no sign of Brown Ring Disease, were obtained from wild populations in the Bay of Brest, France. Clams were maintained in an aerated aquarium with seawater at $15^{\circ} \mathrm{C}$. They were fed daily with cultured phytoplankton. Fluids were sampled 3 to 5 d later

Fiuid sampiing. HiE sanpies were wilhulawn frum the adductor muscle as described by Auffret \& Oubella (1995). Extrapallial fluid samples were collected by drilling holes through the external face of the shell with a round dental burr. Care was taken to avoid cutting the mantle. One hole was made in the central part of each valve to obtain CEF and a second in the sinusal part for the PEF (Fig. 1). The quality of the extrapallial fluid samples was checked by confirmation of mantle integrity after opening the valves. For each clam, the sample volume varied with compartments: 200 to $400 \mu \mathrm{l}$ for HE, 200 to $1000 \mu \mathrm{l}$ for CEF, and 30 to $60 \mu \mathrm{l}$ for PEF (obtained from both valves).

Spontaneous attachment. Samples $(100 \mu \mathrm{from}$ individual clams except for PEF, which were pooled) were discharged onto clean glass slides, then placed in a moist chamber and incubated for $15 \mathrm{~min}$ at room temperature $\left(20^{\circ} \mathrm{C}\right)$. Adhered cells were fixed by flooding the slides with ice-cold $3 \%$ (final concentration) glu-

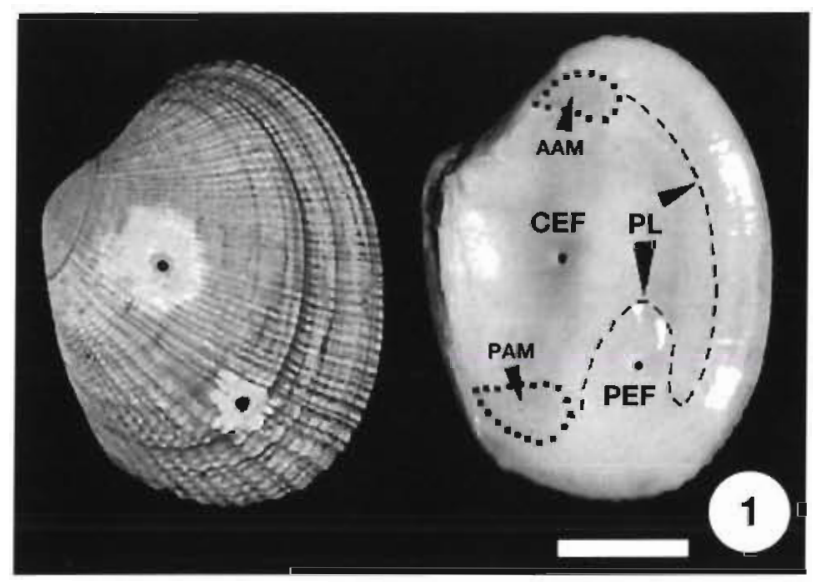

Fig. 1 Ruditapes philippinarum. Extrapallial fluids sampling Holes were made in the central part of the shell for the central extrapallial fluid (CEF) and in the sinusal part for the peripheral extrapallial fluid (PEF). PL: pallial line; AAM: anterior adductor muscle impression. PAM: posterior adductor muscle irapression. Scale bar $=1 \mathrm{~cm}$ taraldehyde seawater. Subsequently, attached cells were rinsed gently in 2 baths of distilled water, air dried and observed directly using phase contrast microscopy (Olympus, BH2).

Cellular parameters. Total and viable cells were counted simultaneously with a hemocytometer in mixtures $(\mathrm{v} / \mathrm{v})$ of sample with $0.2 \%$ trypan blue in seawater. For differential counts, samples were immediately diluted with an ice-cold iso-osmotic anti-aggregant solution (1 l distilled water, $14.4 \mathrm{~g} \mathrm{Na} \mathrm{HPO}_{4} \cdot 2 \mathrm{H}_{2} \mathrm{O}$ $2.6 \mathrm{~g} \mathrm{NaH} \mathrm{PO}_{4} \cdot \mathrm{H}_{2} \mathrm{O}, 25 \mathrm{~g} \mathrm{NaCl}, 10 \mathrm{~g} \mathrm{EDTA} ; \mathrm{pH} 7.4$ ), and centrifuged $(30 \times g, 10 \mathrm{~min}$; cytospin technique). Resulting smears were stained (May-GrünwaldGiemsa stain) according to Auffret \& Oubella (1995) For size measurements, samples were fixed immedidiely in ice-cold $6 \%(v / v)$ ghutaraldehyde seawater to minimize any modification in shape or size, then centrifuged and stained as described above. Resulting smears were observed under a microscope (Leica DRMBE) equipped for image analysis processing (Cohu video camera, Visilog 4 software). Cell diameter was considered equivalent to the diameter of a circle having the same surface area.

Electron microscopy. Spreading cells from HE, CEF and PEF were obtained as described above. They were fixed for $30 \mathrm{~min}$ with $2.5 \%$ glutaraldehyde in $0.2 \mathrm{M}$ sodium cacodylate buffer $(\mathrm{pH} 7.2)$ and adjusted to 1100 mOsm with $\mathrm{NaCl}$. In order to observe the whole cellular population, not only spreading cells, additional samples were immediately fixed $(\mathrm{v} / \mathrm{v})$ in the fixative solution $(5 \%$ glutaraldehyde in cacodylate buffer) for $30 \mathrm{~min}$ on ice; the mixture was then centrifuged (30 $\times g, 10 \mathrm{~min}$; cytospin). Smears prepared according to these 2 techniques were washed with buffer solution $(2 \times 30 \mathrm{~min})$, postfixed for $1 \mathrm{~h}$ in $1 \%$ osmium tetroxide solution (in buffer), rinsed with buffer $(2 \times 30 \mathrm{~min})$, dehydrated in a 70 to $100 \%$ ethanol gradient, dried by the critical point method, coated with gold and observed under scanning electron microscope (SEM Hitachi, S-3200N).

Lysozyme activity. $\mathrm{HE}$ and CEF samples from single clams were assayed individually; PEF samples were pooled because of their small volume $(30$ to $60 \mu \mathrm{l}$ $\left.\mathrm{clam}^{-1}\right)$. Samples were centrifuged $\left(10 \mathrm{~min}, 400 \times g_{1}\right.$ $4^{\circ} \mathrm{C}$ ) and supernatant (SN) was withdrawn and stored at $-20^{\circ} \mathrm{C}$ until used. Sterile (autoclavec and filtered at $0.2 \mu \mathrm{m}$ ) seawater was added to the cell pellet to obtain a final concentration of $10^{6}$ cells $\mathrm{ml}^{-1}$, then sonicated (40 min in ice-cold water). Cell lysate (CL) was stored at $-20^{\circ} \mathrm{C}$ until used. Lysozyme concentration was determined spectrophotometrically according to the method of Shugar (1952). Samples (50 $\mu$ l SN or CL) were added to $1 \mathrm{ml}$ of a bacterial suspension (lyophilized Micrococcus lysodeikticus, $20 \mathrm{mg} \mathrm{ml}$ in $66 \mathrm{mM}$ phosphate buffer at $\mathrm{pH}$ 5.5) and turbimetric changes were 
recorded for $100 \mathrm{~s}$ at $450 \mathrm{~nm}$ (Secoman, S1000 spectrophotometer). Chicken egg white (CEW) lysozyme (Sigma) served as the standard. Lysozyme activity was calculated using the change in absorbance between 10 and $100 \mathrm{~s}$. Supernatant protein was measured by the method of Bradford (1976) using bovine serum albumin as a standard. Lysozyme activity is reported as the concentration of CEW lysozyme equivalent expressed either in $\mathrm{mg}$ per $\mathrm{ml}$ of sample or per $\mathrm{mg}$ protein for the $\mathrm{SN}$, and per ml of sample or per $10^{6}$ cells for the CL.

Bacterial analysis. Only CEF samples were examined for the presence of bacteria. Preliminary studies carried out in our laboratory showed that drilling through the valves resulted in a high risk of bacteriological contamination of the CEF by the pallial fluid. To identify contaminated CEF samples, clams were inoculated in the pallial cavity with a naturally pigmented (red) marine bacterium $\left(5 \times 10^{8}\right.$ colony-forming units $\mathrm{clam}^{-1}$ ), then CEF samples were aseptically with- drawn. Immediately, samples were serially diluted and plated on standard marine agar $[1$ l distilled water, $15 \mathrm{~g}$ agar, $20 \mathrm{~g}$ sea salts (Sigma), $4 \mathrm{~g}$ peptone, $0.1 \mathrm{~g}$ $\left.\mathrm{Fe}\left(\mathrm{PO}_{4}\right)_{2}\right]_{;}$sub-samples were inoculated in standard marine culture broth since this medium is more favorable to bacterial growth than solid agar. Enumeration was made after 2 wk of incubation at $20^{\circ} \mathrm{C}$. Plates containing red colonies were considered to have been contaminated by the pallial fluid during sampling.

\section{RESULTS}

\section{Cellular characteristics}

Observations by light and scanning electron microscopy (Figs. 2 to 5) showed that cells in the clam's CEF and PEF were morphologically similar to hemocytes from the HE. They possessed filipods and were able to
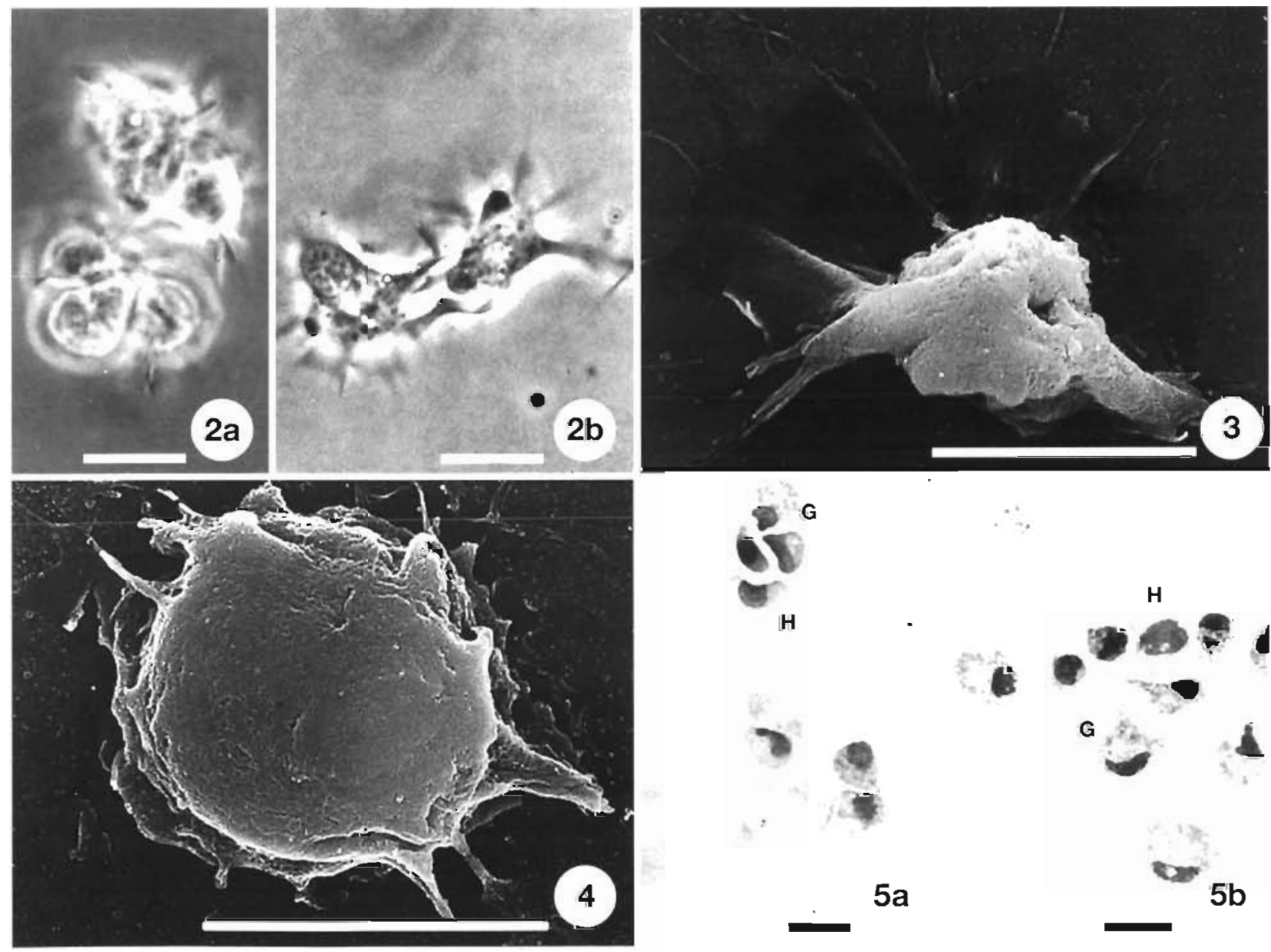

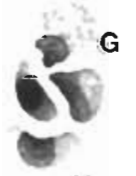

H

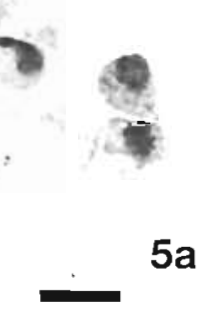

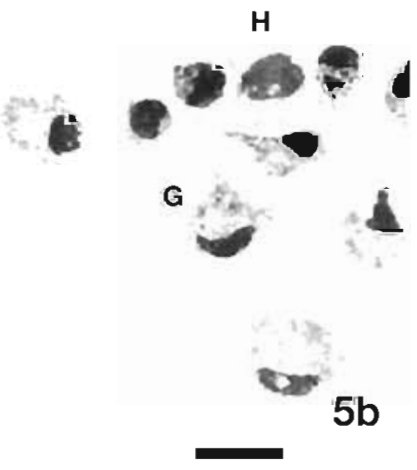

Figs. 2 to 5. Ruditapes philippinarum. Cells found in clam extrapallial fluids and hemolymph (scale bars $=10 \mu \mathrm{m}$ ). Fig. 2 . (a) Aggregated and (b) spreading PEF cells observed under phase contrast microscopy. Fig. 3. Scanning electron micrograph (SEM) of a spreading CEF cell. Fig. 4. SEM of an instantaneously fixed PEF cell shows round shape with short cytoplasmic extensions.

Fig. 5. May-Grünwald-Giemsa staining of (a) CEF and (b) hemolymph cells. G: granulocytes; H: hyalinocytes 
form aggregates of various size (Fig. 2). When placed on glass slides, living cells adhered, formed pseudopods and began migrating (Fig. 3). Preparations of instantaneously fixed cells showed small round cells with short filamentous cytoplasmic extensions (Fig. 4). The sizes of CEF cells and HE hemocytes were statistically the same and ranged from 4.1 to $13.9 \mu \mathrm{m}$ in diameter (Table 1).

Stained preparations of CEF and PEF showed cells with or without cytoplasmic neutrophilic (pink) granules comparable to granulocytes and hyalinocytes encountered in the HE (Fig. 5). These 2 cell types represented more than $95 \%$ of the whole population. The percentage of granular cells was $37.6 \pm 13.6$ in the HE and $39.8 \pm 21.5$ in the CEF (mean \pm standard deviation. $\mathrm{n}=10$, Table 1). Other minor ceij types were observed. particularly vacuolized and unidentified cells.

Relatively large variations occurred in cell concentrations, especially in the CEF $\left(0.8\right.$ to $8.2 \times 10^{6}$ cells $\mathrm{ml}^{-1}$ ). Mean cell concentrations were significantly higher in HE and CEF than in PEF (Table 1). A significant positive correlation ( $r=0.63, \mathrm{p}<0.001, \mathrm{n}=25$ ) was found between cell concentrations in CEF samples withdrawn from each valve of the same clam; however, there was no correlation between concentrations in the $\mathrm{HE}$ and the CEF ( $\mathrm{r}=0.23, \mathrm{p}=0.2, \mathrm{n}=25)$. The large variations found in CEF cell concentrations could not be explained by the large variation in CEF fluid volumes as the two were not correlated $(r=0.09, p=0.66$, $n=25$ ). Cell viability was significantly higher in the CEF and HE than in PEF (Table 1).

\section{Lysozyme}

Lysozyme activity was demonstrated in $\mathrm{HE}$, CEF and PEF. In each compartment, there was more lysozyme activity in the CL than in the SN (Table 1). In CL calculated activity was equivalent to $5.1,6.2$ and $5.8 \mu \mathrm{g}$ CEW lysozyme $\mathrm{ml}^{-1}$ of sample in the HE, CEF and PEF respectively (Table 1), whereas $\mathrm{SN}$ activity equaled $2.4,2.1$ and $1.9 \mu \mathrm{g}$ CEW lysozyme $\mathrm{ml}^{-1}$ of sample in the $\mathrm{HE}, \mathrm{CEF}$ and PEF, respectively (Table 1). However, the standardization of lysozyme activity with total hemocyte count for the CL and with protein contents for the $\mathrm{SN}$ led to substantial changes in these results, with maximal values in the PEF (3.1 $\mu \mathrm{g}$ CEW lysozyme per $10^{6}$ cells and $13.4 \mathrm{\mu g}$ CEW lysozyme $\mathrm{mg}^{-1}$ protein) followed by CEF (3.0 kg CEW lysozyme per $10^{6}$ cells and $10.3 \mu \mathrm{g} \mathrm{CEW}$ lysozyme $\mathrm{mg}^{-1}$ protein) and $\mathrm{HE}(2.7 \mu \mathrm{g}$ CEW lysozyme per $10^{6}$ cells and $6.9 \mu \mathrm{g}$ CEW lysozyme $\mathrm{mg}^{-1}$ protein).

\section{Bacteriology}

Only 3 among 11 CEF samples contained culturable bacteria that were detected on both agar plates and in marine broth. Positive agar plates had predominantly red colonies and were considered to have been contaminated by the pallial fluid during CEF sampling. There were no culturable bacteria in the other 8 samples. Consequently, they were considered to be bacteriologically sterile.

Table 1. Ruditapes philippinarum. Means \pm SD of hemolymph (HE), central (CEF) and peripheral (PEF) extrapallial fluid parameters. Number of individually analyzed clams and pooled samples are indicated within round and square brackets, respectively. Student's 2-tailed $t$-test was used for statistical analysis. Each compartment was tested against the other two. When statistical differences are significant $(p<0.05)$, only the highest $p$-value is indicated within parentheses. NA: not assayed

\begin{tabular}{|c|c|c|c|c|}
\hline & $\mathrm{HE}$ & $\mathrm{CEF}$ & PEF & $\begin{array}{l}\text { Statistical analysis } \\
\text { (Students } t \text {-test) }\end{array}$ \\
\hline Cell diameter $(\mu \mathrm{m})$ & $7.42 \pm 0.47(10)^{\mathrm{d}}$ & $7.60 \pm 0.44(10)^{\mathrm{ct}}$ & NA & $\mathrm{HE}=\mathrm{CEF}$ \\
\hline $\begin{array}{l}\text { Total hemocyte count } \\
\left(10^{6} \mathrm{ml}^{-1}\right)\end{array}$ & $2.42 \pm 0.35(25)$ & $2.88 \pm 1.82$ & $1.94 \pm 0.79(18)$ & $\begin{array}{c}\mathrm{HE}=\mathrm{CEF}>\mathrm{PEF} \\
(\mathrm{p}<0.05)\end{array}$ \\
\hline $\begin{array}{l}\text { Differential hemocyte count } \\
\text { (\% granulocytes) }\end{array}$ & $37.6 \pm 13.6(10)$ & $39.8 \pm 21.5(10)$ & NA & $\mathrm{HE}=\mathrm{CEF}$ \\
\hline Cell viability $(\%)$ & $95.6 \pm 3.3(25)$ & $97.0 \pm 4.1$ & $86.2 \pm 6.0(18)$ & $\begin{array}{c}\mathrm{HE}=\mathrm{CEF}>\mathrm{PEF} \\
\left(p<10^{-6}\right)\end{array}$ \\
\hline Supernatant protein $\left(\mathrm{mg} \mathrm{ml}^{-1}\right)$ & $0.35 \pm 0.12$ & $0.20 \pm 0.04$ & $0.14 \pm 0.02[6]^{b}$ & $\begin{array}{c}\mathrm{HE}>\mathrm{CEF}>\mathrm{PEF} \\
(p<0.02)\end{array}$ \\
\hline $\begin{aligned} \text { Cell lysate lysozyme as } \mu \mathrm{g} \mathrm{m} \mathrm{m}^{-1} & \\
& \mu \mathrm{g} \text { per } 10^{6} \text { cells }\end{aligned}$ & $\begin{array}{l}5.1 \pm 1.7 \\
2.7 \pm 1.2 \\
(25)\end{array}$ & $\begin{array}{l}6.2 \pm 1.7 \\
3.0 \pm 2.1 \\
(25)\end{array}$ & $\begin{array}{l}5.8 \pm 2.1 \\
3.1 \pm 0.6 \\
{[6]^{\mathrm{b}}}\end{array}$ & $\begin{array}{c}C E F>P E F=H E \\
H E=C E F=P E F \\
(p<0.02)\end{array}$ \\
\hline $\begin{array}{l}\text { Supernatant lysozyme as } \mu \mathrm{g} \mathrm{ml}^{-1} \\
\qquad \mu \mathrm{g} \mathrm{mg} \mathrm{g}^{-1} \text { protein }\end{array}$ & $\begin{array}{l}2.4 \pm 1.3 \\
6.9 \pm 4.7 \\
(25)\end{array}$ & $\begin{array}{c}2.1 \pm 1.1 \\
10.3 \pm 6.5 \\
(25)\end{array}$ & $\begin{array}{c}1.9 \pm 0.9 \\
13.4 \pm 3.9 \\
{[6]^{b}}\end{array}$ & $\begin{array}{c}\mathrm{HE}=\mathrm{CEF}=\mathrm{PEF} \\
\mathrm{CEF}=\mathrm{PEF}>\mathrm{HE} \\
(\mathrm{p}<0.05)\end{array}$ \\
\hline \multicolumn{5}{|l|}{$\begin{array}{l}\text { 'Number of cell measured } \geq 250 \text { cells clam }{ }^{-1} \\
{ }^{3} 3 \text { clams pool }\end{array}$} \\
\hline
\end{tabular}




\section{DISCUSSION}

The major result of the present paper was the consistent observation of numerous hemocytes in extrapallial fluid of clams that have the same morphological, cytometrical and cytological characteristics as HE hemocytes. Cell concentrations in CEF and PEF were similar to those found in the HE of the same individuals. Hemocytes from extrapallial fluids (CEF and PEF) were in good condition when tested using the trypan blue exclusion method and SEM observations. They have been shown to phagocytose latex beads and the pathogenic Vibrio tapetis labeled with the fluorochrome cyanoditolyl tetrazolium chloride (Allam et al. 1995, Allam \& Paillard unpubl. data). The presence of putative hemocytes in shell fluids of oysters was recently documented (Muholland \& Friedl 1994, Paillard et al. 1996). Mulholland \& Friedl (1994) and Mulholland et al. (1995) showed that hemocytes from oyster shell liquor, pericardial cavity and adductor muscle sinuses have the same cytometric characteristics as those demonstrated by multifactorial analysis. These findings raise questions concerning the origin and role of the extrapallial hemocytes in undisturbed bivalve species, and about the distinction between internal and external fluids in bivalves.

(1) The extrapallial fluid hemocytes probably originate from diapedesis from the mantle. Intensive infiltrations of hemocytes from blood sinuses into the connective tissue and into the extrapallial space through the external mantle epithelium has been reported after shell damage in several molluscan species (Wagge 1955, Beedham 1965, Bayne 1983). The role of infiltrating hemocytes has not been clearly defined (Wilbur 1964, Watabe 1983). They probably play a role in shell repair, perhaps by transporting metabolites needed for the repair process (Beedham 1965). They may also play a role in the defense process by constituting an immunological barrier following damage inflicted to the main physical barrier (Beedham 1965, Watabe 1983, Fisher 1986).

(2) Depending on a bivalve's anatomy, the extrapallial space can be a single compartment or divided into two. If the mantle is strongly bound to the shell at the pallial line, the attachment separates the central compartment from the peripheral; the former is relatively isolated from the ambient water, whereas the latter is more open to it (as in clams). If the mantle is not strongly attached at the pallial line, it can retract, leaving the extrapallial compartment relatively open to the ambient water (as in oysters). In spite of these large morphological differences between clams and oysters, the presence of hemocytes has been confirmed in the extrapallial fluid of both of these species (Muholland \& Friedl 1994, Allam et al. 1995, Paillard et al. 1996).
Even if exchange between seawater and shell fluids occurs, the environment between the mantle and the shell is sufficiently closed to be considered as a 'pseudo-internal' compartment. Following this approach, the shell fluids in bivalves can be considered as 'pseudo-internal' fluids that may act, in addition to supporting shell growth processes, like the HE to preserve bivalve health.

Lysozyme activity has been documented in the $\mathrm{HE}$ of many marine bivalve species (Chu 1988). This bacteriolytic enzyme is active against several species of Gram-positive and Gram-negative bacteria (Cheng \& Rodrick 1974, Rodrick \& Cheng 1974, McHenery \& Birkbeck 1982). Our results show the presence of lysozyme activity in Manila clam extrapallial fluids as well as in the HE. Unlike the soft-shelled clam Mya arenaria (Cheng \& Rodrick 1974), lysozyme activity in Manila clams is more abundant in cell lysate than in supernatant, as is the case with the HE of Mercenaria mercenaria (Cheng et al. 1975). Previous results based on semi-quantitative enzyme determinations (apiZYM galerie, Biomérieux, France) showed very close enzymatic profiles between cell lysates and supernatants from the HE, CEF and PEF of Manila clams (Allam et al. 1995). The origin of lysozyme and other enzymes in the CEF and PEF supernatant could be the lysosomes of granular hemocytes as in the case of HE serum (Cheng \& Rodrick 1974, Rodrick \& Cheng 1974, Cheng 1981). However, mantle epithelial cell secretions (e.g. lysosome contents and mucus) may contribute to the enzymatic and bacteriolytic activity in these fluids.

The bacteriological sterility of CEF revives controversy on the assumption of sterility of molluscan body fluids. Many authors consider that molluscan HE contains endogenous bacterial microflora (Olafsen et al. 1993). In our study, technical sampling difficulties were solved by making holes through polished and sterilized (sprinkled with alcohol) shell and not through epiflora-rich soft tissues. CEF sterility can result from one or both of the following factors: (1) effectiveness of the physical barrier constituted by the shell, the mantle, and the pallial muscle attachment that prevents microbial invasion, and (2) defense factors present in the CEF (numerous macrophage-like cells, lysozyme activity, and perhaps other antibacterial factors) that neutralize invading microorganisms.

In conclusion, defense factors, represented by abundant hemocytes and a bacteriolytic enzyme, are described in clam extrapallial fluids. High similarities (total and differential hemocyte counts, and lysozyme activities) were observed between $\mathrm{HE}$ and extrapallial fluid factors, especially with CEF. In addition, the CEF is bacteriologically sterile. These findings are particularly relevant in the case of bivalves susceptible to shell diseases, such as Ruditapes philippinarum, which 
is affected by Brown Ring Disease of the shell caused by the bacterium Vibrio tapetis. The role of abundant hemocytes in extrapallial fluids remains to be defined. They undoubtedly play a role in metabolite transport and the calcification process. However, it seems that they also act in the defense process since:experimental infection with $V$. tapetis enhances cell concentrations and lysozyme activity in the CEF (Allam unpubl.). Additional experiments are in progress to clarify the role of extrapallial fluids in the bivalve defense strategy.

Acknowledgements. This work was supported by a fellowship from the French Government - Ministère des Affaires Etrangères in cooperation with the Lebanese Marine Research Center (Batroun, Lebanon). We are grateful to Di C. Quentel and M. F. Lamour from the Centre National d'Etudes Vétérinaires et Alimentaires (CNEVA, Brest) for their help and advice for lysozyme measurement, to $M$. G Sinquin for his technical assistance with the scanning electron microscopy, and to Mrs Friocourt for correcting the manuscript. Special thanks go to Dr Susan Ford from the Haskin Shellfish Research Laboratory (N.J, USA) for valuable comments on the manuscript.

\section{LITERATURE CITED}

Allam B, Oubella R, Pajllard C, Maes P, Auffet A (1995) The extrapallial fluid: an additional element in the defense system of clams? In: Paillard C. Ford SE (eds) International workshop on shell disease in marine invertebrates: environment-host-pathogen interactions. March 29-31 Brest. France, p 49-50 (Abstract)

Auffret M, Oubella R (1995) Cytological and cytometric analysis of bivalve mollusc hemocytes. In: Stolen JS, Fletcher TC, Smith SA, Zelikoff JT, Kaattari SL, Anderson RS, Söderhäll K, Weeks-Perkins BA. (eds) Techniques in fish immunology, Vol 4. SOS Publications, Fair Haven, NJ, p 55-64

Bartoli P (1974) Recherches sur les gymnophallidae F.N Morzov, 1955 (Digenea), parasites d'oiseaux des côtes de Camargue: systématique, biologie et écologie. Thèse de doctorat d'Etat, Université d'Aix-Marseille

Bayne CJ (1983) Molluscan immunobiology. In: Saleuddin ASM, Wilbur KM (eds) The mollusca. Physiology, Vol 5 , Part 2. Academic Press, San Diego, p 407-486

Beedham GE (1965) Repair of the shell in species of Anodonta. Proc Zool Soc Lond 145:107-125

Borrego JJ, Castro D, Luque A, Paillard C, Maes P, Garcia MT, Ventosa A (1996) Vibrio tapetis sp. nov, the causative agent of the brown ring disease affecting cultured clams. Int J Syst Bacterio! 46(2):480-484

Bradford MM (1976) A rapid and sensitive method for the quantitation of microgram quantities of protein utilizing the principal of protein-dye binding. Anal Biochem 72: $248-254$

Cheng TC (1981) Bivalves. In: Ratcliffe NA, Rowley AF (eds) Invertebrate blood cells, Vol 1 Academic Press, London, p 231-300

Cheng TC, Rodrick GE (1974) Identification and characterization of lysozyme from the hemolymph of the soft shelled clam, Mya arenaria. Biol Bull (Woods Hole) 147:311-320

Editorial responsibility: Albert Sparks,

Seattle, Washington, USA
Cheng TC, Rodrick GE, Foley DA, Koehler SA (1975) Release of lysozyme from hemolymph cells of Mercenaria mercenaria during phagocytosis. J Invertebr Pathol 25:261-265

Chu FLE (1988) Humoral defense factors in morine bivalves. Am Fish Soc Spec Publ 18:178-188

Crenshaw MA (1972) The inorganic composition of molluscan extrapallial fluid. Biol Bull (Woods Hole) 143:506-512

Fisher WS (1986) Structure and function of oyster hemocytes. In: Bréhelin $M$ (ed) Immunity in invertebrates. SpringerVerlag, Heidelberg, p 25-35

Fisher WS (1992) Occurrence of agglutinins in the pallial cavity mucus of oysters. J Exp Mar Biol Ecol 162:1-13

McDade JE, Tripp MR (1967) Lysozyme in oyster mantle mucus. J Invertebr Pathol 9:581-582

McHenery JG, Birkbeck TH (1982) Characterization of the lysozyme of Mytilus edulis (L.). Comp Biochem Physiol $71 \mathrm{~B}(4): 583-589$

Misogianes M.J, Chasteen ND (1979) A chemical and spectral characterization of the extrapallial fluid of Mytilus edulis. Anal Biochem 100:324-334

Mulholland DS, Friedl FE (1994) Cytometric analyses of oyster hemocytes from various body locations. Annual meeting. National Shellfisheries Association, Charleston, SC, p 29-30 (Abstract)

Mulholland DS, Friedl FE, Alvarez MR (1995) Image cytometry of bivalve hemocytes. In: Stolen JS, Fletcher TC, Smith SA, Zelikoff JT, Kaattari SL, Anderson RS, Söderhäl] $\mathrm{K}$. Weeks-Perkins BA (eds) Techniques in fish immunology, Vol 4. SOS Publications, Fair Haven, NJ, p 65-72

Olafsen JA, Mikkelsen HV, Giaever HM, Hansen GH (1993) Indigenous bacteria in hemolymph and tissues of marine bivalves at low temperature. Appl Environ Alicrobiol 59(6): $1848-1854$

Paillard C. Ashton-Alcox K, Ford SE (1996) Changes in bacterial densities and hemocyte parameters in eastern oyster, Crassostrea virginica, affected by juvenile oyster disease. Aquat Living Resour 9:145-158

Paillard C, Maes P (1990) Etiologie de la maladie de l'anneau brun chez Tapes philippinarum: pathogénicité d'un Vibrio sp. C R Acad Sci Ser III 310:15-20

Paillard C, Maes P (1994) Brown ring disease in the Manila clam Ruditapes philippinarum: establishment of a classification system. Dis Aquat Org 19:137-146

Paillard C, Maes P, Oubella R (1994) Brown ring disease in clams. Annu Rev Fish Dis 4:1-22

Paillard C, Perclay L, Le Pennec M, Le Picard D (1989) Origine pathogène de l'anneau brun chez Tapes philippinarum (mollusque, bivalve). C R Acad Sci Ser III 309: $235-241$

Rodrick GE, Cheng TC (1974) Kinetic properties of lysozyme from the hemolymph of Crassostrea virginica. J Invertebr Pathol 24:41-48

Shugar D (1952) Measurement of lysozyme activity and the ultraviolet inactivation of lysozyme. Biochem Biophys Acta 8:302-309

Wagge LE (1955) Amoebocytes. Int Rev Cytol 4:31-78

Watabe N (1983) Shell repair. In: Saleuddin ASM, Wilbur KM (eds) The mollusca, Vol 4, Part 1. Academic Press, New York, p 28.9-316

Wilbur KM (1964) Shell formation and regeneration. In: Wilbur KM, Yonge CM (eds) Physiology of Mollusca, Vol 1 Academic Press, New York, p 243-282

Wilbur KM, Saleuddin ASM (1983) Shell formation. In: Saleuddin ASM, Wilbur KM (eds) The mollusca, Vol 4. Part 1. Academic Press, New York, p 235-287 